\title{
多角的アプローチによる新規生活習慣病治療戦略の開発研究
}

\author{
宮本理 人 $a, b$
}

\section{Novel Strategies for Treating Lifestyle-related Diseases Using Various Approaches}

\author{
Licht Miyamoto ${ }^{a, b}$ \\ ${ }^{a}$ Laboratory of Pharmacology and Physiological Sciences, Frontier Laboratories for Pharmaceutical Sciences, Faculty of \\ Pharmaceutical Sciences, Tokushima University; and ${ }^{b}$ Department of Medical Pharmacology, Institute of Biomedical \\ Sciences, Tokushima University Graduate School; 1-78-1 Sho-machi, Tokushima 770-8505, Japan.
}

(Received September 8, 2015)

\begin{abstract}
The number of patients with metabolic disorders is dramatically increasing all over the world. The diseases often exhibit multiple metabolic disturbances including diabetes, hyperlipidemia, and obesity, and so on, recognized as a concept of metabolic syndrome. It is important to consider the common underlying pathophysiological bases of such metabolic diseases at the suggestion of the teachings of a parable, "The blind men and an elephant," whereby each blind man investigates a different part of the elephant. The lesson could even be applicable to each aspect of the disorders. Physical exercise as well as dietetics harbor versatile preventive and therapeutic potency against diverse metabolic diseases. Thus further investigation into molecular and physiological mechanisms underlying beneficial effects of therapeutic exercise and diet will provide us with significant clues to the elephant behind the disorders. Moreover, it could be of great benefit if such non-drug treatments, which may be hard to achieve for most patients, were replaced with medication. Recently, we demonstrated evidence that activators of 5' AMP-activated protein kinase (AMPK) could be satisfactory exercise mimetics in terms of metabolome. In this review, metabolomic analysis on the significant roles of AMPK in contracting skeletal muscles is described. In addition, our novel prodrug strategy providing extremely hydrophobic agents with marked hydrophilicity by conjugation with branched glycerol oligomers, which can be widely applicable in general to drug design for good pharmacokinetic properties in drug discovery, is introduced.
\end{abstract}

Key words — metabolic syndrome; 5'AMP-activated protein kinase; metabolome; physical exercise; prodrug; hydrophobic agent

\section{はじめに}

糖尿病，肥満，高血圧などといつた，代謝疾患の 多くは遺伝的要因に加え，生活習慣がその病態発 症，進展に深く係わることが知られている。近年の 生活様式の変化に伴い, 代謝疾患を呈する患者の増 大がわが国だけではなく世界中で大きな問題となつ ている。糖尿病だけをみても, 国際糖尿病連合 (International Diabetes Federation; IDF) の調査に よると 2014 年時点での糖尿病有病率は成人の 8.3 \%と推定され，その患者数は世界第 3 位である米国 の全人口を凌ぐ $\left.{ }^{1}\right)$

\footnotetext{
$a$ 徳島大学薬学部総合薬学研究推進室生理化学解析薬理 研究室, $b$ 徳島大学医歯薬学研究部医薬品機能生化学分 野 (干770-8505 徳島市庄町 1-78-1) e-mail: licht_corresp2011@yahoo.co.jp 本総説は, 平成 26 年度日本薬学会中国四国支部奨励賞 の受賞を記念して記述したものである.
}

筆者は薬学部, 医学部臨床講座, 民間企業研究所 など，様々な研究環境をこれまでに経験し，生体内 エネルギー代謝制御のメカ二ズム研究及び，糖尿病 や肥満症を中心とする代謝疾患の病態基盤解明と創 薬を含めた治療戦略の開発研究に携わつてきた。研 究の目的やアプローチは大幅に異なるものの, 様々 な考え方，立場の人々とともに，一貫して代謝疾患 に係わることにより, 生理, 病態, 薬理, 治療, 創 薬，育薬などといつた多様な見方，アプローチの仕 方を少しは身につけられたように思う.

「群盲象を評す」という言葉がある。例えばここ では 2 型糖尿病の病因, 病態の発現や抑制, 治療標 的に関係するとされる分子や現象などのキーワード を近年の論文からピックアップしてみた (Fig. 1). 2 型糖尿病の病態基盤にはインスリン分泌不全とイ ンスリン抵抗性が重要と考えられているが, ここに 挙げられたような分子，現象などそれぞれの因子を 


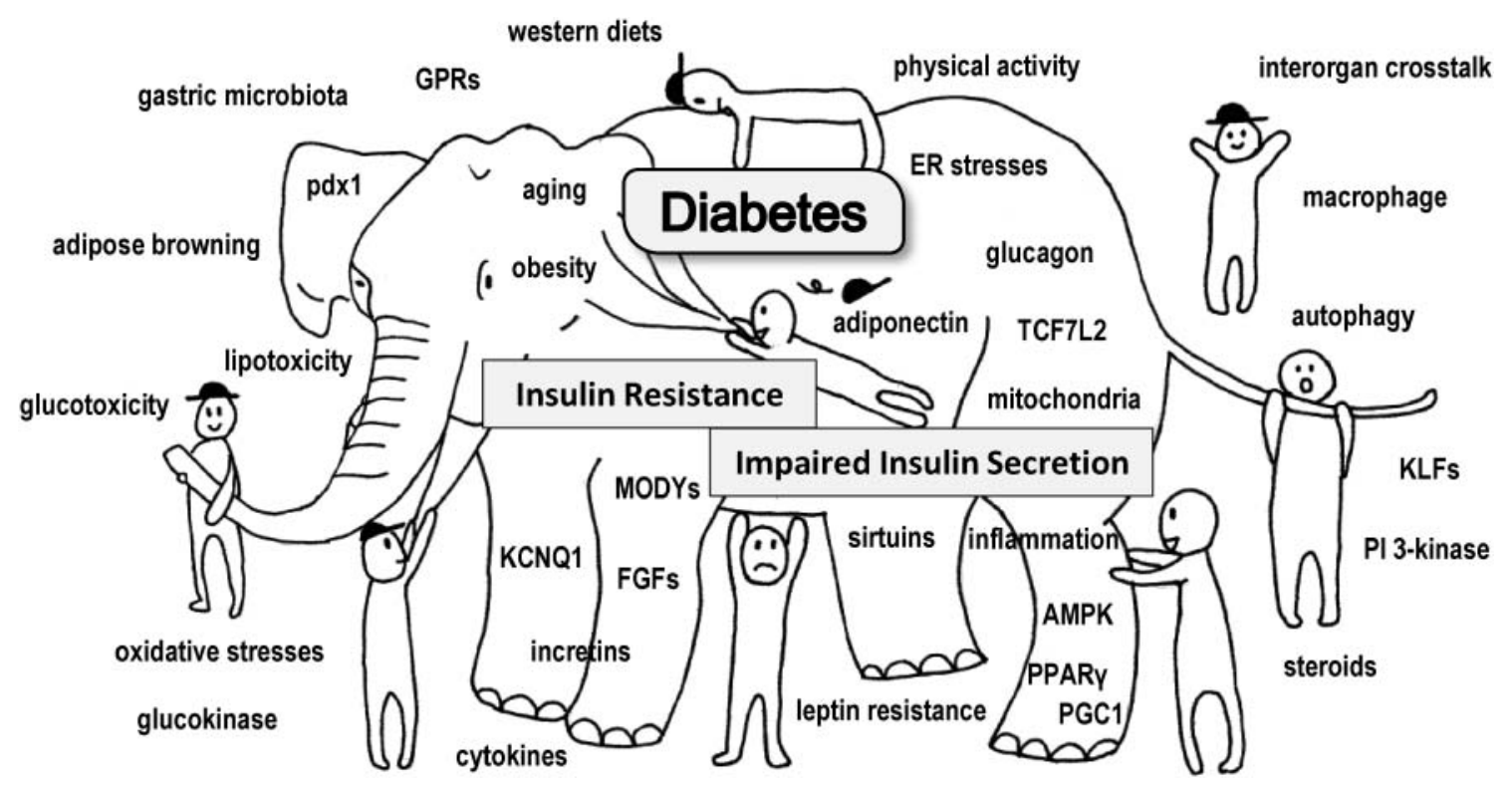

Fig. 1. Molecules, Factors and Phenomena Featured in Recent Reports Related to Pathophysiology and/or Potential Therapeutic Targets of Diabetes - Isn't It a Parable of the Blind Men and an Elephant?-

断片的に取り上げることでどの程度病態や治療の本 質に迫れるか，自戒の念も込めて，よく考えなけれ ばならないであろう。われわれは後述する運動療法 の分子機序研究に端を発した，5'AMP-activated protein kinase (AMPK) という代謝制御の鍵分子に 注目した研究を展開する一方で，これまでの様々な 経験を活かし, 共同研究を含む多様なテーマに取り 組み, 代謝疾患の病態基盤や創薬を含む治療戦略開 発に迫りたいと考えている。本稿では誌面の制限も あり，「多角的アプローチ」とのタイトルとはほど 遠いが，収縮筋のメタボロミクス的解析による運動 療法模倣薬創出の試夕と, 難水溶性化合物の親水性 を向上し，創薬の成功に導くための試みについて紹 介したい。

骨格筋収縮時のメタボローム変化における AMPK の役割と運動療法模倣薬創出の可能性

運動療法は食事療法とともに代謝疾患の予防と治 療に臨床応用されている。これらの効果は非常に幅 広く, 様々な代謝疾患を総合的に予防, 治療するた めに役立つことが知られている。実際，メタボリッ クシンドロームの基盤をなす, 糖尿病, 肥満症, 脂 質異常症などといつた各疾患に対してはそのすべて において運動療法と食事療法が治療ガイドラインで 第一選択療法として位置づけられている. ${ }^{2-6)}$ なか でも糖尿病に対しては，身体運動がインスリン非依 存的に直接血糖值を下げることに加え, インスリン

感受性を亢進する作用も有していることから運動療 法の高い効果が考えられる.

身体運動が血糖值を下げる機序としては, 特に収 縮筋における急性の糖取り込みの増大とそれに続く インスリン感受性六進が古くより知られてい る. ${ }^{7-11)}$ 自転車など，下肢の大きな骨格筋を使う運 動の効果が高いのはこのためであると言える. しか しながら，その分子機序が明らかになってきたのは ここ 15 年ほどのことである. 運動療法の分子機序 研究が進むきつかけの 1 つとなつたのは AMPK 仮 説と呼ばれる，収縮筋における AMPK の活性化が 糖の取り込み増大やインスリン感受性亢進を引き起 こすという考え方である. 単離骨格筋をバッファー 中で電気刺激により収縮させると, 糖取り込みの増 大とともに, AMPK という分子が強く活性化され る. AMPK の活性化剤である5-aminoimidazole-4carboxamide-1- $\beta$-D-ribonucleoside (AICAR) を用い て同様に単離骨格筋を刺激すると, AMPK 活性化

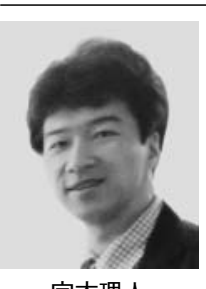

宮本理人
東京大学薬学部卒業, 同大学院薬学系 研究科修士課程修了 (生理化学教室). 京都大学博士 (医学). 民間企業研究 員, マネージャー, 主任を経て, 京都 大学医学部附属病院内分泌代謝内科助 教（産学官連携）。2011 年より徳島大 学にて勤務. 2013-15 年総合薬学研究 推進室特任助教 (PI) を併任. 同 7 月 より医薬品機能生化学分野助教. 
とともに，糖取り込み増大も生じる。これらの強度 や阻害剂感受性プロファイルなどの高い類似性か ら，骨格筋収縮時に生じる糖取り込み増大における AMPK 活性化の重要性が提唱された. ${ }^{12,13)}$ 近年の多 くの研究により，AMPK が細胞内エネルギーレベ ルの低下を検知する，いわばエネルギーセンサーと して機能し, 代謝状態を同化から異化優位へと変化 させる，糖代謝，脂質代謝調節の最も重要な制御因 子の 1 つであることが明らかとなり，AMPK 活性 化は糖取り込夕促進のみならず，骨格筋収縮時にお ける様々な代謝変化を媒介すると考えられるように なってきた。実際，AICAR による単離骨格筋刺激 や個体への投与によりインスリン感受性や脂質代謝 の充進が生じるなど，多くの実験結果がより広い概 念としての AMPK 仮説を支持してきた. ${ }^{14-23)}$ 一方, AMPK や関連する分子に係わる遺伝子改変動物も 数多く作製された。 それらの解析結果はかならずし も一貫していないものの，むしろ，骨格筋収縮時の 代謝制御における AMPK 非依存的な経路の重要性 を示唆する報告も多く，骨格筋収縮時の AMPK の 役割には大きな疑問が残された. ${ }^{24-28)}$ そこで，われ われは従来とは異なる解析アプローチとして近年急 速に発達してきたメタボロミクス的手法を用い，収 縮筋における代謝状態の変化を網羅的に明らかにす るとともに, AMPK 依存性, 非依存性の代謝経路 の解明を試みた. ${ }^{29)}$

メタボロミクスとは細胞内，生体内などの代謝産 物を網羅的に解析するシステム生物学的アプローチ の 1 つであり，そのための手法として，多くの物質 を同時に定量可能なメタボローム解析の技術が近年 急速に発展している．現在，メタボローム解析には 核磁気共鳴法（NMR）や質量分析法（MS）と種々 のクロマトグラフィー技術を組み合わせて用いるの が一般的であり，それぞれ得手不得手がある. ${ }^{30)}$ わ れわれの解析では骨格筋中の糖代謝関連分子を解析 することに重きを置き，低分子量極性分子の解析に 秀でた，キャピラリー電気泳動-飛行時間型質量分 析法 (capillary electrophoresis time-of-flight mass spectrometry；CE-TOFMS 法）を採用した.

正常 SD ラットから単離した滑車上肘筋に対し, 最大に AMPK 活性化を引き起こす条件を用いて バッファー中にて ex vivo でテタヌス刺激又は AICAR 刺激し，刺激した骨格筋サンプル中のメタボ
ローム解析を CE-TOFMS 法にて行った. このとき AMPK 活性を確認すると，われわれがこれまで報 告してきたように, $\alpha 1, \alpha 2$ いずれのアイソフォー ムも 3-4 倍と, AICAR 刺激及び骨格筋刺激により 同程度の活性化が生じており，さらに糖取り込み活 性もいずれの刺激によっても同じように約 4 倍六進 していた [Figs. 2(A)-(C)]. ${ }^{15,29)}$

この条件下でメタボロームの変化を解析したとこ ろ, 184 本のピーク検出に成功し, うち 132 分子に ついて定量が可能なレベルであった。これら全 132 分子の AICAR 刺激による変化を X 軸に, 筋収縮 による変化を $\mathrm{Y}$ 軸にプロットしたものが Fig. 2(D) である. メ夕ボローム全体にわたつて非常に高い類 似性が一目瞭然に見て取れるであろう。実際，AICAR 刺激時と骨格筋収縮時のメタボローム変化は 強い正の相関を示し，AMPK の薬理学的活性化が 骨格筋刺激時の代謝変化を広範囲にわたり模倣可能 であることを示している．代謝経路別に分けて各分 子の動きをサブ解析すると，解糖系や TCA 回路な ど糖代謝に係わる分子群，NAD 代謝や核酸代謝に 関わる分子群などで高い相関が認められたのに対 し，アスパラギン酸，アラニン，リジンなど，一部 のアミノ酸代謝に関連する分子群では相関が認めら れず，骨格筋収縮時のメタボローム変化における AMPK 依存性シグナルの幅広い役割が示唆される 一方で，アミノ酸代謝の一部は AMPK 非依存性シ グナルにより支配されていると考えられた. ${ }^{29)}$

この結果を多変量解析の代表的手法の 1 つ, 主成 分分析 (principal component analysis; PCA) を用 いてさらに解析した。コントロールと AICAR 刺激 時，筋収縮時のメ夕ボローム状態は 132 次元空間上 に各分子の変化量をプロットすることで得られる が，そのままでは直感的に特徵を把握するのは困難 である．高次元でもユークリッド空間にて 3 点を通 る平面は 1 枚しか存在しないため, これら 3 点の位 置関係は情報量を失わずに二次元平面上に投影可能 であるが，このとき PCA を活用すると，最も 3 点 の特徵（違い）を表せる主要な評価軸（PC1）を決 めることができる.この PC1 と残りのマイナーな 評価軸（PC2）の各々に分けて 3 点の位置関係を示 した [Fig. 2(E)]。最も各点の特徵を反映するメ ジャーな成分である PC1 では AICAR 刺激と筋収 縮がほぼ同じ位置に現れ，コントロールと反対に位 
A

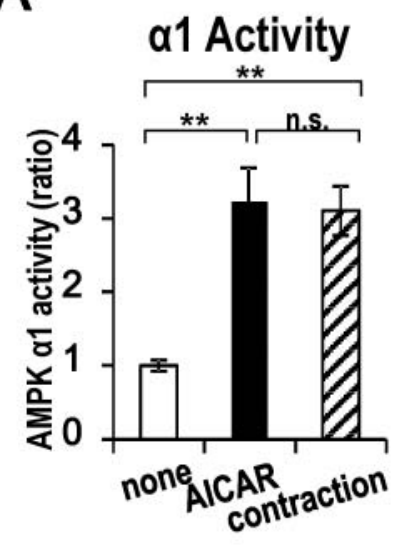

C
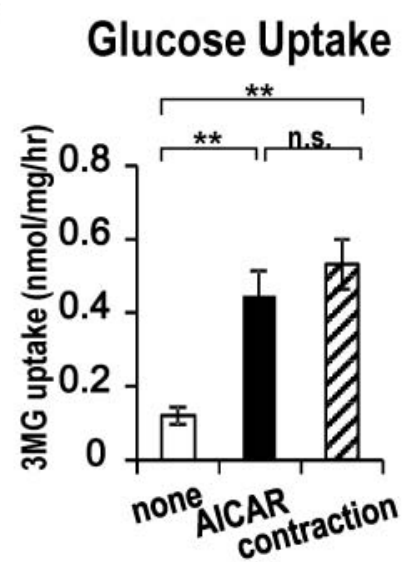

B

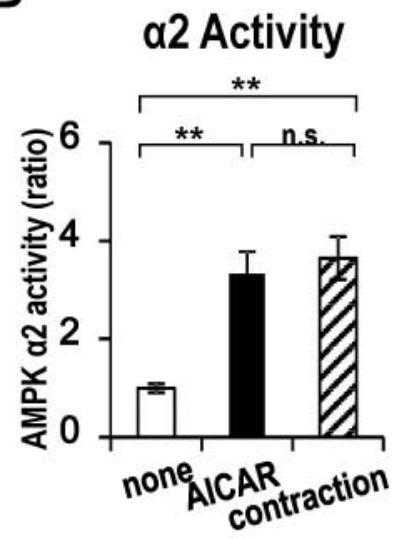

E
D

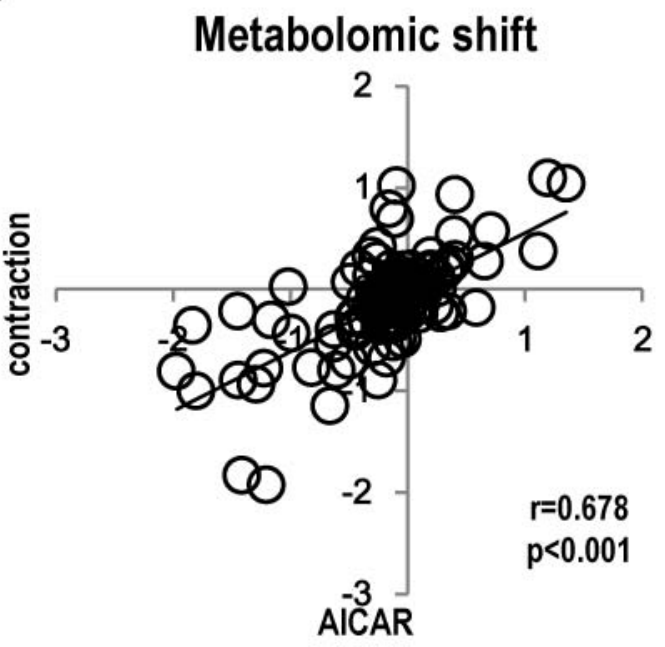

Fig. 2. Pharmacological Activation of AMPK by AICAR Stimulation Mimics Metabolic Alterations in Contracting Skeletal Muscles Metabolome-widely

Activities of AMPK $\alpha 1$ (A), $\alpha 2$ (B) and glucose uptake (C) in isolated rat epitrochlearis muscles after stimulation by 2 mM AICAR for 40 min (closed bars) and electrical contraction ex vivo (hatched bars). Metabolomic shifts evoked by the AICAR stimulation (X-axis) and electrical contraction (Y-axis) (D). Principal component scores of the quiescent control (open circle), AICAR stimulation (closed triangle) and electrical contraction (hatched square) (E). ${ }^{*} p<0.01$; n.s., not significant.

置することから, AICAR 刺激時と筋収縮時のメ夕 ボロームの高い類似性が確認され，さらに，PC1 の構成成分は両者の共通するシグナル，すなわち AMPK 依存性のシグナルにより制御される経路に 関連することが示された。一方，マイナーな成分で ある PC2 ではコントロールが中央に, AICAR 刺 激と筋収縮が同程度正負に乘離することから，AICAR 刺激時と筋収縮時のメ夕ボロームの差異は主 要な違いではなく，さらに，PC2 の構成成分は AMPK 非依存性のシグナルにより制御される経路 に関連すると考えられた。

引き続き因子分析を用いて AICAR 刺激時と筋収 縮時の共通するシグナルに係わる因子の更なる解析 をしたところ，還元型グルタチオンが最上位の分子

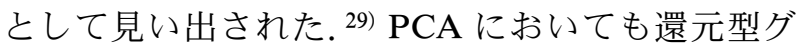

ルタチオンは PC1 の因子負荷量の 2 番目に大きい 分子であり (PC1: 0.0923, PC2:-0.001), 筋収縮時 に生じる AMPK 依存性メタボローム状態変化にお いて酸化還元電位の変化が重要であることが示唆さ れた．筋収縮時には酸化ストレスが生じる一方で,

AMPK は概ね抗酸化的に作用すると考えられてい ることから，この結果には当初疑問が抱かれた。し かし，様々な実験系で検証したところ，AMPK の 急性の活性化直後には筋収縮時と同様，還元型グル タチオンの減少が起こり, 酸化還元電位は酸化側に 傾こうとしていることが判明した. ${ }^{29)}$ この一見予想 に反した作用が筋収縮時に生じる AMPK 依存性メ タボローム状態変化に重要であると，PCA 並びに 因子分析の結果より裏付けられたことは大変興味深 く，今後更なる解析を行っていきたい．さらにこの 
結果より, AMPK 活性化時に生じる抗酸化的な作 用はこの急性の作用に対する代償的な反応の結果で あることが推測され，AMPKによる代謝制御の新 たな作用機序解明にもつながったと考えている.

これらの結果は，AICARのような AMPK 活性 化剂がメタボロミクスの観点から見て良好な運動療 法模倣薬となり得ることを示している. ${ }^{29,30)}$ 入院中 の患者はもとより, 多くの人達にとつて継続的な運 動療法の実施は残念ながら容易ではない。代謝疾患 の夕ならず極めて広範囲な予防，治療効果を有する 身体運動の効果を一部でも薬物治療で置き換えるこ とができれば多くの患者に恩恵をもたらすであろう。

分岐鎖オリゴグリセロールを用いた難水溶性化合 物の物性, 薬物動態, 及び, 薬効の改善

次に，近年われわれが共同研究にて開発している 汎用性の高い技術として，分岐鎖オリゴグリセロー ル（branched oligoglycerol; BGL）を用いた親水性 向上技術について紹介したい.

創薬において薬物動態は重要かつハードルの高い 関門の 1 つである. In vitro や細胞レベルで高い活 性を示す化合物であっても，in vivoにて投与した ときに，十分に吸収され，適切に標的組織に分布し なければ個体レベルで十分な薬効は発現しない。良 好な薬物動態のためには化合物の親水性-疎水性バ ランスを適切にデザインすることが重要であるが, 高い生理活性と満足な親水性一疎水性バランスを両 立することはかならずしも容易ではない，実際，創 薬の現場では親水性に欠ける候補化合物の水溶性向 上に難儀することが非常に多い，そこで，われわれ は本学，根本尚夫准教授らとともに BGL を用いた 親水性向上技術の開発にも取り組んでいる.

分岐鎖グリセロール三量体（BGL003）の構造を Fig. 3 (A) に示した. BGL003 は分子量約 240 と小 さな分子にもかかわらず多くの水酸基を有し，親水 性が非常に高いうえ，不斉炭素を持たない対称な分 子である. ${ }^{31,32)}$ よって，疎水性の高い化合物に結合 するだけで, 光学異性体を生じることなく高い親水 性を付与可能な新たな機能性分子として期待される [Fig. 3(B) ]。 また，七量体など，より大きな BGL を用い，さらに高い親水性を供与することも可能で

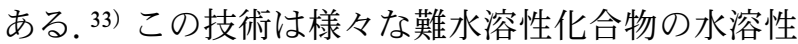
向上に応用可能であり，われわれも検討を行ってい るが，ここではフェノフィブラートでの例について
紹介する. ${ }^{31,34-37)}$

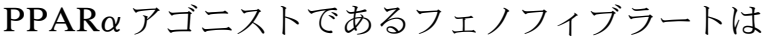
脂質異常症治療薬として臨床的に広く用いられてい るが，疎水性が極めて高くほとんど水溶性を有しな いため，微粉末化などの製剤改良がなされてきた。 われわれはこの疎水性薬剤の典型例として知られる フェノフィブラートの BGL 誘導体 [FF-BGL; Fig. $3(\mathrm{C})$ ］をデザイン，合成し，物性，薬物動態及び 薬効の検討を行つた.

まず，FF-BGL の水への溶解度を検討したところ， $2.3 \mathrm{mg} / \mathrm{mL}$ 程度と見積もられ，検出限界以下で あったフェノフィブラートと比べて少なくとも 2000 倍以上の水溶性改善が認められた [Fig. 3 (D) ]. ${ }^{31)}$ 次に, 正常ラットに等モル数のフェノ フィブラート及び FF-BGL を単回投与し，血中の 薬物濃度推移を検討したところ, FF-BGL はフェノ フィブラートに比べ，4-5 倍程度高い值を示した [Fig. 3(E)]. なおこのとき，投与直後から血中に FF-BGL は検出されず，フェノフィブラート同様, 活性代謝産物であるフェノフィブリン酸 （fenofibric acid; FA）のみが検出されたことなどか ら，この化合物では BGL 部分が投与後速やかに切 断され，即効性プロドラッグとして機能しているこ とも確認された. ${ }^{34)}$ 結合部分のドラッグデザインの 仕方により，薬物動態の特徵を制御し得る点も BGL の長所の 1 つと言えるだろう。また，難水溶 性化合物の吸収は空腹時に低下することが知られて おり，フェノフィブラート製剂も食後投与が指示さ れている. しかし，フェノフィブラートと異なり， 親水性の向上した FF-BGL の血中薬物濃度の AUC は絶食時の投与でも低下せず，服薬時間の自由度が 高いと考えられることから，服薬コンプライアンス 向上などの点でも有利であろう $[\mathrm{Fig.} \mathrm{3(F)].}$

さらに，FF-BGL の薬効を高脂肪食負荷マウスに て検討したところ，FF-BGL はフェノフィブラート より分子量が 1.5 倍大きいにもかかわらず， $1 / 10$ の投与量でほぼ同程度の血中中性脂肪低下作用を示 し，また高用量では遊離脂肪酸レベルの低下も認め られるなど，フェノフィブラートより明らかに強い 血中脂質指標改善作用が認められた [Figs. 3(G) and $(\mathrm{H})] .{ }^{34)}$ 以上より，BGL を用いた誘導体化は 難水溶性化合物の物性のみならず，薬物動態や薬効 を著しく改善する効果が期待できると言える. 
<smiles>OCC(O)COC(CO)CO</smiles>
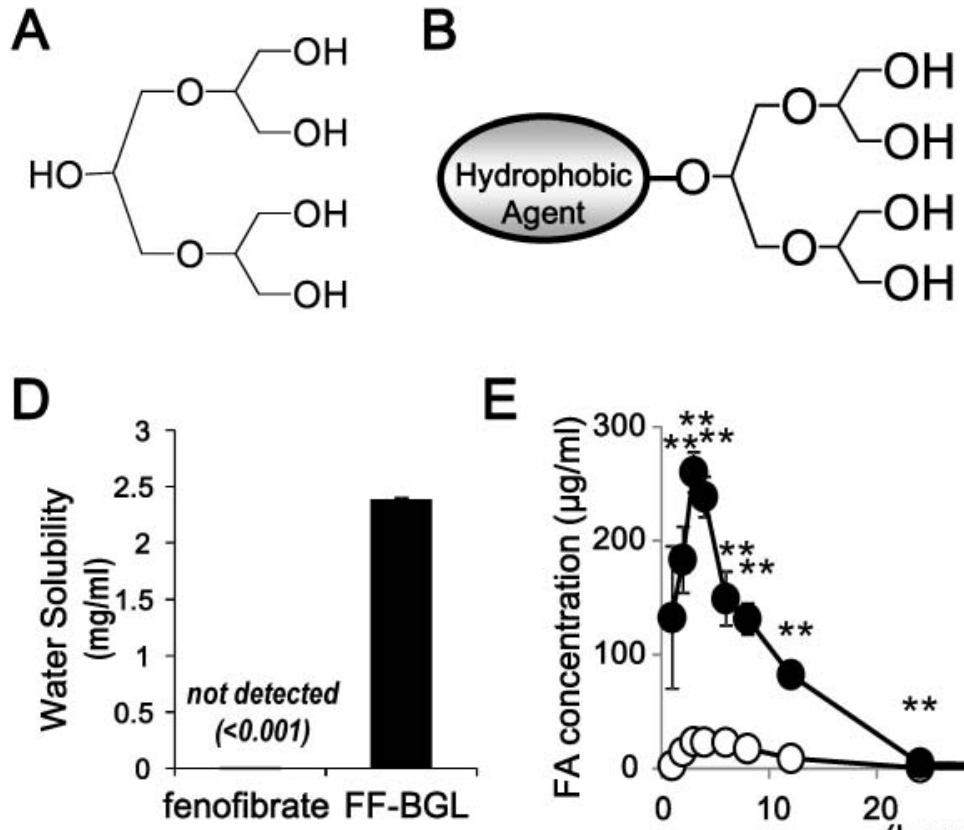

C<smiles>CC(C)(OC(COC(CO)CO)COC(CO)CO)C(=O)OC1CCC(C(=O)c2ccc(Cl)cc2)CC1</smiles>

$\mathbf{F}$

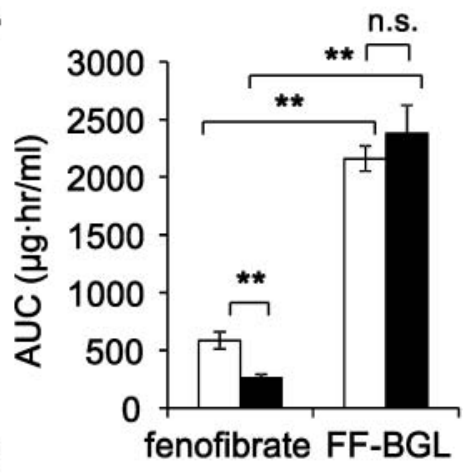

G

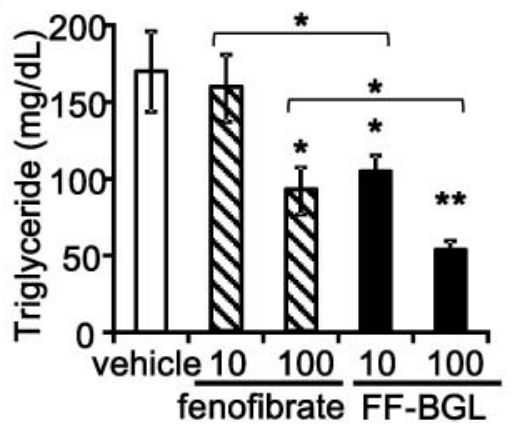

$\mathrm{H}$

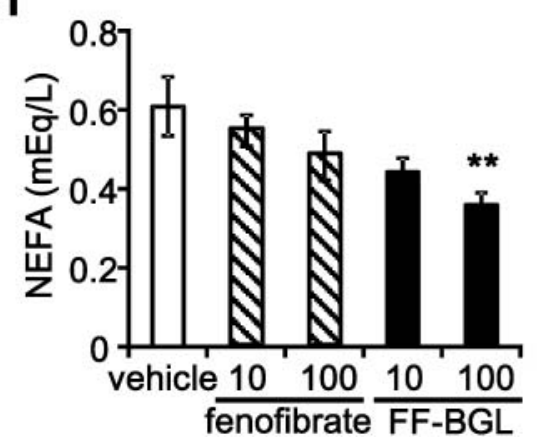

Fig. 3. Conjugation to Symmetrically Branched Glycerol Trimer Improves Hydrophilicity, Pharmacokinetic and Pharmacological

Properties of Fenofibrate

Structural formula of symmetrical branched glycerol trimer, BGL003 (A). A schematic concept how to use BGL003 to endow hydrophobic agents with hydrophilicity (B) and structural formula of BGL003-conjugated fenofibrate (FF-BGL) (C). Water-solubility of fenofibrate and FF-BGL (D). Plasma concentration of fenofibric acid (FA) after single oral administration of $0.277 \mathrm{mmol} / \mathrm{kg}$ body weight of fenofibrate (open circles) and FF-BGL (closed circles) in SpragueDawley rats after half-day fasting (E). The area under the curve at ad libitum feeding (open bars) or fasting condition (closed bars) (F). Triglycerides (G) and nonesterified fatty acid (NEFA) (H) levels in the plasma after seven-day repetitive oral administration of $10 \mathrm{or} 100 \mathrm{mg} / \mathrm{kg} / \mathrm{d}$ of fenofibrate (hatched bars) and FFBGL (closed bars) in high fat diet-fed mice. ${ }^{*} p<0.05 ;{ }^{*} p<0.01$; n.s., not significant.

現在似たような目的で多く用いられているポリエ チレングリコール (polyethylene glycol; PEG) と 比較すると，分岐鎖オリゴグリセロールは対称な単 一分子であるため, 結合したすべての分子の挙動が 均一であることが推定できるほか，分子量がはるか に小さく, 投与量が少なくてすむこと, 分解されて も毒性の高いエチレングリコールを生じる可能性が ないことなどが長所として挙げられる。実際, BGL003 は食品などにも利用されているグリセロー ルと同様, 細胞毒性やマウスにおける急性経口毒性 を示すことなく, 化学品の分類に関する国際規格,
GHS の基準で最も安全な化合物カテゴリーである ハザードカテゴリー 5 に分類される安全性の高い物 質であることが既に確認されている. ${ }^{31,35)}$

望ましい物性, 薬物動態及び薬効実現のために, 標的化合物のどの部分にどのようなリンカー構造を 用いて BGL を付加するべきかという点に関するノ ウハウはまだ十分に確立されていないが，BGL は 既知化合物の再利用を含め, 創薬における新たな汎 用性の高い技術になり得るとわれわれは期待してい る. 


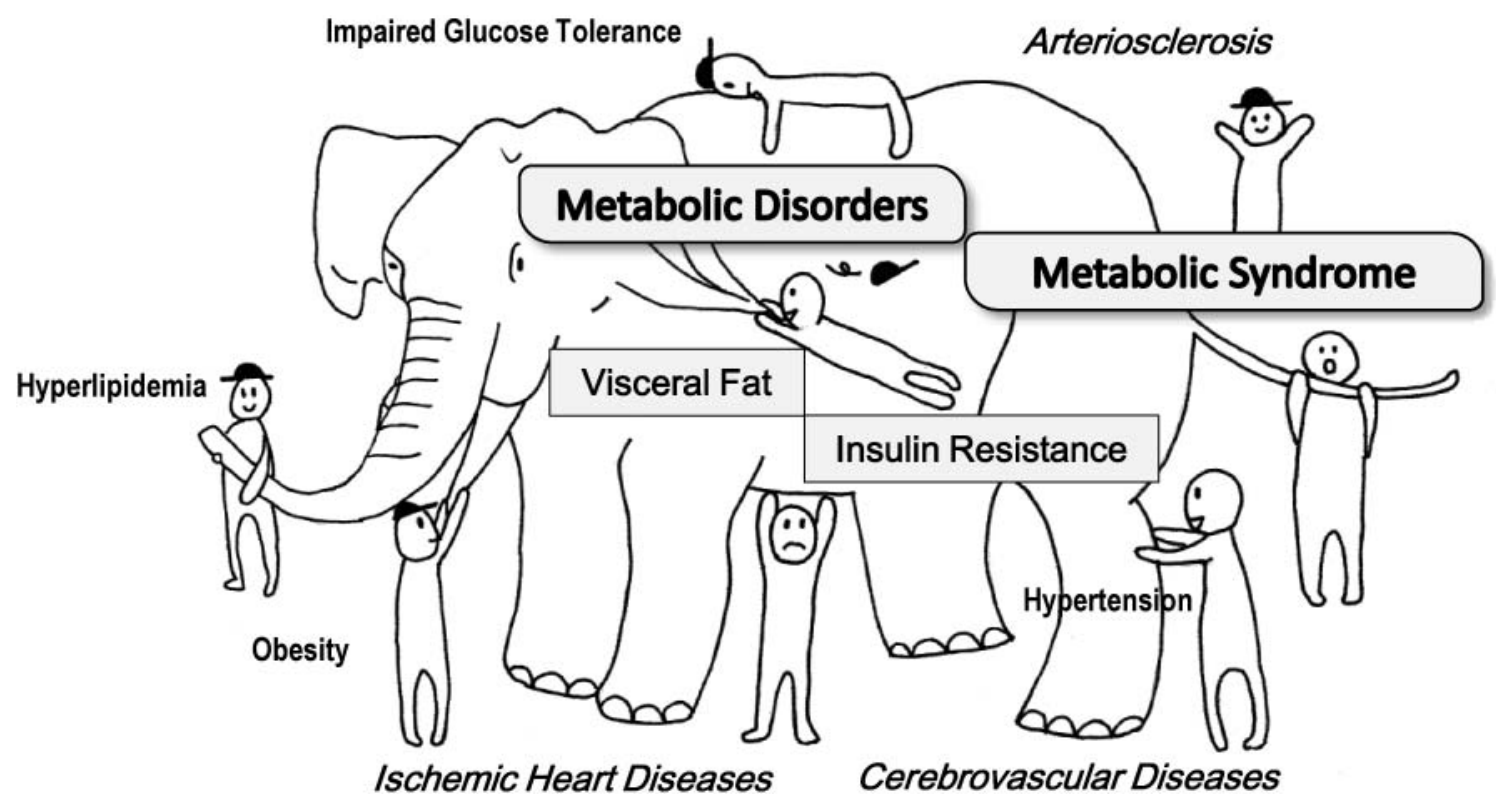

Fig. 4. Pathological Conditions in Patients with Multiple Metabolic Disorders like Metabolic Syndromes — Isn't It also a Parable of the Blind Men and an Elephant? -

\section{おわりに}

近年メタボリックシンドロームの概念として整理 されつつあるように，代謝疾患はしばしば様々な病 態が複合的に発症し，死に直結するような重篤な血 管障害を引き起こす。このような患者では，糖尿病 や高血圧，脂質異常症など，各々の患者の体質など によって現れ易い病態から表出すると考えられる. これらの各疾患をただそれぞれが合併，併発してい ると捉えただけでは，メタボリックシンドロームに みられるような複合的な代謝疾患の病態の正しい理 解や根本的な治療に迫るのは難しい。代謝疾患の多 くは痛みなど自覚症状を伴わず，虚血性心疾患や脳 血管障害による致命的なイベント発生に至るまで診 断，治療がなされないケースも少なくない。より早 い段階での予防，診断方法の開発を含め，複合的疾 患のなるべく根本に近いところでの介入が可能にな るよう, 病態の本質的な理解が求められている. メ タボリックシンドロームの根幹をなす病変として,

内臓脂肪の蓄積やインスリン抵抗性の関与が考えら れているが, 病態の本質にどこまで迫れているかは いまだ検証が必要な段階と言える (Fig. 4).

このような複合的な代謝疾患に対し，現状では 「群盲象を評す」の域を脱していないのかもしれな いが，かなずしも悲観的になる必要はない。前述の 通り, 運動療法と食事療法が様々な代謝疾患に関し
て幅広く有効であることをわれわれは経験的によく 知っている.これら非薬物療法の作用機序を解明す ることにより，メタボリックシンドロームに代表さ れるような複合的代謝疾患の病態の本質に迫ること ができるのではないかと私は考えている，運動療法 や食事療法は代謝疾患の重要な予防，治療戦略の 1 つであるだけでなく，がんや認知症など高齢化社会 の進行に伴い増加している多くの疾患に対しても有 効性が期待されているが, 継続的実施が難しいとい う欠点がある。非薬物療法でも作用機序の詳細が明 らかになれば新たな薬物治療, 創薬への展開が可能 であろう。われわれはこのような非薬物療法をヒン 卜にした創薬, 探索研究に対しても「多角的アプ ローチ」の重要な一角として引き続き力を入れて取 り組む所存である。また，今後とも，これまでに 培つたユニークな経歴, 経験, ネットワークを活か し，代謝疾患の病態基盤の解明と創薬を含めた治療 戦略の開発を目指した多様なアプローチの活用を試 みることで, 薬学の発展と医療への貢献, 後進の研 究者や薬剂師育成にも引き続き力を尽くしていきた い.

謝辞 学生時代の恩師である, 東京大学 堅田 利明教授, 現広島大学 櫨木 修教授を始め, これ までの様々な研究を遂行するにあたりご指導頂きま 
した多くの先生方，お世話になつた多くの方々に御 礼申し上げます。本稿でご紹介した研究では特に, 徳島大学 土屋浩一郎教授，BGL の開発者である根 本尚夫准教授, 徳島文理大学 堤一彦特任教授, AMPK 仮説の提唱者である京都大学 林 達也教授 にご指導頂くとともに，様々な助成団体にもお力添 え頂きました，最後に，土屋教授，挿絵を描いてく れた土橋有希さん，芳野真奈さんを始め, 現在日々 一緒に活動している徳島大学医薬品機能生化学分野 の皆さんにこの場を借りて改めて感謝申し上げます.

\section{利益相反＼cjkstart開示すべき利益相反はない.}

\section{REFERENCES}

1) International Diabetes Federation, "IDF Diabetes Atlas 6th edition-2014 update," 2014.

2) Albright A., Franz M., Hornsby G., Kriska A., Marrero D., Ullrich I., Verity L. S., Med. Sci. Sports Exerc., 32, 1345-1360 (2000).

3) Berglund L., Brunzell J. D., Goldberg A. C., Goldberg I. J., Sacks F., Murad M. H., Stalenhoef A. F., J. Clin. Endocrinol. Metab., 97, 2969-2989 (2012).

4) Jaques H., Eur. Heart J., 34, 481-482 (2013) .

5) Jaques H., Eur. Heart J., 34, 406-408 (2013).

6) Sim K., "Global Guideline for Type 2 Diabetes," International Diabetes Federation, 2012.

7) Mondon C. E., Dolkas C. B., Reaven G. M., Am. J. Physiol., 239, E169-E177 (1980).

8) Richter E. A., Garetto L. P., Goodman M. N., Ruderman N. B., J. Clin. Invest., 69, 785793 (1982).

9) Holloszy J. O., Narahara H. T., J. Gen. Physiol., 50, 551-562 (1967).

10) Holloszy J. O., Narahara H. T., J. Biol. Chem., 240, 3493-3500 (1965).

11) Ivy J. L., Holloszy J. O., Am. J. Physiol., 241, C200-C203 (1981).

12) Hayashi T., Hirshman M. F., Fujii N., Habinowski S. A., Witters L. A., Goodyear L. J., Diabetes, 49, 527-531 (2000) .

13) Hayashi T., Hirshman M. F., Kurth E. J., Winder W. W., Goodyear L. J., Diabetes, 47, 1369-1373 (1998).

14) Miyamoto L., Ebihara K., Kusakabe T., Aotani D., Yamamoto-Kataoka S., Sakai T.,
Aizawa-Abe M., Yamamoto Y., Fujikura J., Hayashi T., Hosoda K., Nakao K., J. Biol. Chem., 287, 40441-40447 (2012).

15) Miyamoto L., Toyoda T., Hayashi T., Yonemitsu S., Nakano M., Tanaka S., Ebihara K., Masuzaki H., Hosoda K., Ogawa Y., Inoue G., Fushiki T., Nakao K., J. Appl. Physiol., 102, 1007-1013 (2007).

16) Nakano M., Hamada T., Hayashi T., Yonemitsu S., Miyamoto L., Toyoda T., Tanaka S., Masuzaki H., Ebihara K., Ogawa Y., Hosoda K., Inoue G., Yoshimasa Y., Otaka A., Fushiki T., Nakao K., Metabolism, 55, 300-308 (2006).

17) Bergeron R., Previs S. F., Cline G. W., Perret P., Russell R. R. 3rd, Young L. H., Shulman G. I., Diabetes, 50, 1076-1082 (2001).

18) Bergeron R., Ren J. M., Cadman K. S., Moore I. K., Perret P., Pypaert M., Young L. H., Semenkovich C. F., Shulman G. I., Am. J. Physiol. Endocrinol. Metab., 281, E1340E1346 (2001).

19) Ojuka E. O., Jones T. E., Nolte L. A., Chen M., Wamhoff B. R., Sturek M., Holloszy J. O., Am. J. Physiol. Endocrinol. Metab., 282, E1008-E1013 (2002).

20) Fisher J. S., Gao J., Han D. H., Holloszy J. O., Nolte L. A., Am. J. Physiol. Endocrinol. Metab., 282, E18-E23 (2002).

21) Song X. M., Fiedler M., Galuska D., Ryder J. W., Fernström M., Chibalin A. V., WallbergHenriksson H., Zierath J. R., Diabetologia, 45, 56-65 (2002).

22) Iglesias M. A., Ye J. M., Frangioudakis G., Saha A. K., Tomas E., Ruderman N. B., Cooney G. J., Kraegen E. W., Diabetes, 51, 2886-2894 (2002).

23) Iglesias M. A., Furler S. M., Cooney G. J., Kraegen E. W., Ye J. M., Diabetes, 53, 16491654 (2004).

24） Fujii N., Hirshman M. F., Kane E. M., Ho R. C., Peter L. E., Seifert M. M., Goodyear L. J., J. Biol. Chem., 280, 39033-39041 (2005) .

25) Jørgensen S. B., Viollet B., Andreelli F., Frøsig C., Birk J. B., Schjerling P., Vaulont S., Richter E. A., Wojtaszewski J. F., J. Biol. Chem., 279, 1070-1079 (2004).

26) Mu J., Brozinick J. T. Jr., Valladares O., Bucan M., Birnbaum M. J., Mol. Cell, 7, 1085- 
1094 (2001)

27) Sajan M. P., Bandyopadhyay G., Miura A., Standaert M. L., Nimal S., Longnus S. L., Van Obberghen E., Hainault I., Foufelle F., Kahn R., Braun U., Leitges M., Farese R. V., Am. J. Physiol. Endocrinol. Metab., 298, E179-E192 (2010).

28) Miura S., Kai Y., Kamei Y., Bruce C. R., Kubota N., Febbraio M. A., Kadowaki T., Ezaki O., Am. J. Physiol. Endocrinol. Metab., 296, E47-E55 (2009).

29) Miyamoto L., Egawa T., Oshima R., Kurogi E., Tomida Y., Tsuchiya K., Hayashi T., Am. J. Physiol. Cell Physiol., 305, C1214-C1222 (2013).

30) Miyamoto L., J. Phys. Fitness Sports Med., 4, 93-102 (2015).

31) Miyamoto L., Watanabe M., Kono M., Matsushita T., Hattori H., Ishizawa K., Nemoto H., Tsuchiya K., J. Toxicol. Sci., 37, 10591063 (2012).

32) Nemoto H., Kikuishi J., Yanagida S., Kawano T., Yamada M., Harashima H., Kiwada H.,
Shibuya M., Bioorg. Med. Chem. Lett., 9, 205-208 (1999).

33) Nemoto H., Kamiya M., Minami Y., Araki T., Kawamura T., Synlett, 2091-2095 (2007) .

34) Miyamoto L., Watanabe M., Taoka C., Kono M., Tomida Y., Matsushita T., Kamiya M., Hattori H., Ishizawa K., Abe S., Nemoto H., Tsuchiya K., Mol. Pharm., 10, 2723-2729 (2013).

35) Miyamoto L., Watanabe M., Tomida Y., Kono M., Fujii S., Matsushita T., Hattori H., Ishizawa K., Nemoto H., Tsuchiya K., J. Toxicol. Sci., 37, 1253-1259 (2012).

36) Nemoto H., Katagiri A., Kamiya M., Kawamura T., Matsushita T., Matsumura K., Itou T., Hattori H., Tamaki M., Ishizawa K., Miyamoto L., Abe S., Tsuchiya K., Bioorg. Med. Chem., 20, 5559-5567 (2012).

37) Nemoto H., Kamiya M., Nakamoto A., Matsushita T., Matsumura K., Hattori H., Kawamura T., Taoka C., Abe S., Ishizawa K., Miyamoto L., Tsuchiya K., Bioorg. Med. Chem. Lett., 22, 6425-6428 (2012). 